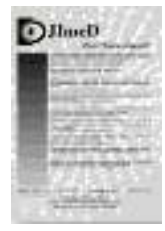

Jurnal Imejing Diagnostik (JImeD) 6 (2020) 69-78

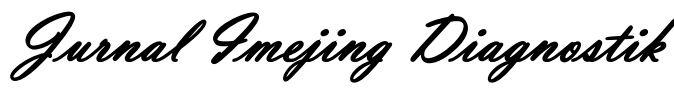

e-ISSN 2621-7457, p-ISSN 2356-301X

\title{
Teknik 3D Conformal Radioterapi (3DCRT) Pada Keganasan Sinus Paranasal Dengan Modalitas Linac
}

\author{
Fitri Agustina ${ }^{1}$, Jeffri Ardiyanto ${ }^{2}$, Siti Masrochah ${ }^{3}$ \\ ${ }^{1}$ Instalasi Radioterapi Rumah Sakit Dr. Sardjito Yogyakarta, Indonesia \\ ${ }^{2}$ Poltekkes Kemenkes Semarang, Indonesia \\ Corresponding author: Fitri Agustina \\ E-mail: najlaku14@gmail.com
}

Received: June $13^{\text {rd }}, 2020$; Revised: June 17 ${ }^{\text {th }}, 2020$; Accepted: June $30^{\text {th }}, 2020$

\begin{abstract}
Background: Radiotherapy is a radiation therapy action using ionizing radiation. To obtain the maximum dose of radiation in the tumour and the lowest possible dose on critical organs required a technique of radiation technique 3 Dimensional Conformal Radiotherapy (3DCRT). Radiotherapy Unit Radiology Installation Dr Sardjito Hospital Yogyakarta using 3DCRT technique. This research aims to know the radiotherapy procedure on paranasal sinus cancer using 3DCRT technique, to know the implementation of bolus beam modifier and dose optimization with the addition of electron radiation.

Methods: The type of research in this thesis is qualitative research with case study approach. The research was conducted at Radiotherapy Unit Radiology Installation Dr Sardjito Hospital Yogyakarta after published Ethical Clearance. Methods of data collection in this study are observation, interviews, and documentation. Result: The results of this study indicate that the radiotherapy procedure in paranasal sinus cancer using 3DCRT technique can produce a homogeneous dose distribution, the implementation of bolus beam modifier is capable of generating dosage homogeneity on uneven target surfaces, and the distribution of doses with electron radiation on the target in the surface area can be optimal.

Conclusion: With these techniques, the goal of radiotherapy can be achieved is to give the maximum dose in the tumour and the minimum dose possible in healthy tissue located in the vicinity.
\end{abstract}

Keywords: 3DCRT; Bolus; Electron Radiation.

\section{Pendahuluan}

Kanker sinus paranasal merupakan pertumbuhan sel (ganas) yang terjadi pada sinus paranasal dalam rongga hidung dan dibatasi serta dilindungi oleh tulang-tulang wajah sehingga tumor yang timbul di daerah ini sulit diketahui secara dini (Carrau, 2013; NN, 2017). Tumor hidung dan sinus paranasal pada umumnya jarang ditemukan dengan prosentase kanker sinonasal sekitar 1: 100.000 orang pertahun di negara berkembang baik yang jinak maupun yang ganas (Shavilla et al., 2016). Di Indonesia dan di luar negeri, angka kejadian jenis yang ganas hanya sekitar 1\% dari keganasan seluruh tubuh atau 3\% dari seluruh keganasan di kepala dan leher. Asal tumor primer juga sulit untuk ditentukan, apakah dari hidung atau sinus karena biasanya pasien berobat dalam keadaan penyakit telah mencapai tahap lanjut dan tumor sudah memenuhi rongga hidung dan seluruh sinus (Siregar, 2005; Soepardi et al., 2007).

Pada umumnya ada beberapa metode pengobatan kanker sinus paranasal antara lain pembedahan, kemoterapi, dan radioterapi, bahkan bisa dilakukan secara kombinasi antara pembedahan, kemoterapi dan radiasi (Lesmono, 2015; Slomski, 2002). Pembedahan sebagai tindakan kuratif sejak lama telah diterima sebagai pengobatan terpilih dan pembedahan tidak dilakukan apabila dijumpai keganasan tumor pada dasar tengkorak, keterlibatan nasofaring dan tumor yang masif dalam sinus sfenoidales (Dhingra, 2010). Saat ini kombinasi pembedahan dan radiasi pascabedah terbukti memberikan hasil pengobatan yang lebih baik (Susworo, 2006).

Radioterapi merupakan tindakan terapi radiasi dengan menggunakan radiasi pengion yang dapat dilakukan pada primer pascabedah maupun primer 
prebedah yang bertujuan untuk mematikan sel tumor sebanyak mungkin dengan melindungi organ sehat disekitarnya. Untuk mencapai tujuan tersebut, maka diperlukan perencanaan terapi radiasi yang teliti, mengingat lokasi anatomis berdekatan dengan mata dan jaringan vital lainnya (Susworo, 2006).

Tujuan utama dari radioterapi adalah memberikan dosis yang letal kepada target volume tetapi dengan dosis sekecil-kecilnya pada organ at risk sekitar. Untuk mencapai ini maka dapat menggunakan teknik konformal. Dengan teknik tersebut, massa tumor dan organ kritis dapat didelineasi dan terindentifikasi dengan baik dan arah sinar dapat dibuat sedemikian rupa sehingga dosis pada organ kritis dapat minimal dan dosis pada target dapat maksimal (Beyzadeoglu et al., 2010).

Untuk menunjang keberhasilan suatu terapi radiasi pada kanker sinus paranasal diperlukan suatu alat bantu yang disebut Beam Modifier dan radiasi elektron yang bertujuan untuk memodifikasi bentuk berkas dan distribusinya. Beam modifier ini diantaranya adalah kolimator, bolus, wedge filter, dan kompensator. Bolus merupakan material yang ekuivalen dengan jaringan yang ditempatkan didekat permukaan tubuh untuk meningkatkan dosis permukaan atau mengkompensasi jaringan yang hilang. Elektron adalah partikel sebuah atom yang bermuatan negatif dan ketika dipercepat, dia dapat menyerap ataupun memancarkan energi dalam bentuk foton. Dalam terapi radiasi, berkas elektron dihasilkan oleh pemercepat linear accelerator untuk pengobatan tumor superficial. Pada kasus kali ini teknik radioterapi yang digunakan pada penyinaran kanker sinus paranasal adalah teknik 3DCRT (3D Conformal Radioterapi) dengan penambahan bolus dan radiasi elektron (Aird \& Conway, 2002).

\section{Metode}

Jenis penelitian pada skripsi ini adalah penelitian kualitatif dengan pendekatan studi kasus yang bertujuan untuk mengetahui prosedur teknik radioterapi 3DCRT pada pasien kanker sinus paranasal, mengetahui implementasi penggunaan alat bantu beam modifier bolus, dan mengetahui optimalisasi hasil kurva isodosis dengan penggunaan elektron.

Subyek penelitian pada skripsi ini adalah 1 orang Dokter Spesialis Onkologi Radiasi, 1 orang Fisikawan Medis, 1 orang Radioterapis CT Simulator, 1 orang Radioterapis di Penyinaran, 1 orang Dokter Pengirim, dan 1 orang pasien kanker sinus paranasal.

Metode penelitian dilakukan dengan cara observasi, wawancara, dan dokumentasi

\section{Hasil dan Pembahasan}

1. Teknik radioterapi $3 D$ Conformal Radioterapi (3DCRT) pada pasien kanker sinus paranasal a.Paparan Kasus

Seorang pasien perempuan umur 57 tahun dari poliklinik THT dikirim ke Unit Radioterapi Instalasi Radiologi RSUP Dr. Sardjito Yogyakarta dengan diagnosis ca sinonasal

b.Perencanaan Radioterapi

Tatalaksana radioterapi kanker sinus paranasal di RSUP. Dr. Sardjito Yogyakarta dimulai dari pasien datang mendaftar, perencanaan radioterapi, saat dilakukan penyinaran, sampai selesai radioterapi. Tatalaksana radioterapi kanker sinus paranasal ini dikerjakan oleh tim yaitu Dokter Onkologi Radiasi, Fisika Medis, Radiografer dan petugas lainnya. Pemeriksaan ini dilakukan secara terprogram dengan perjanjian waktu penyinaran.

c. CT Simulator

1) Posisi Pasien : supine diatas meja pemeriksaan

2) Kepala diberi fiksasi head baseplate dan headrest dengan kode " $3 / 4$ "

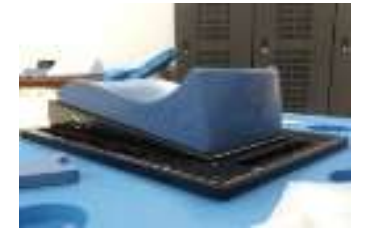

Gambar 1. Bantalan kepala

3) Mengatur posisi pasien sedemikian rupa sehingga posisi kepala dan tubuh searah dengan laser sagital, koronal dan aksial atau true AP dan true Lateral

4) Melakukan proses dual scanogram (AP dan Lateral) dari vertex sampai fossa supraklavikula.

5) Mereview posisi kepala dan leher untuk true AP dan Lateral.
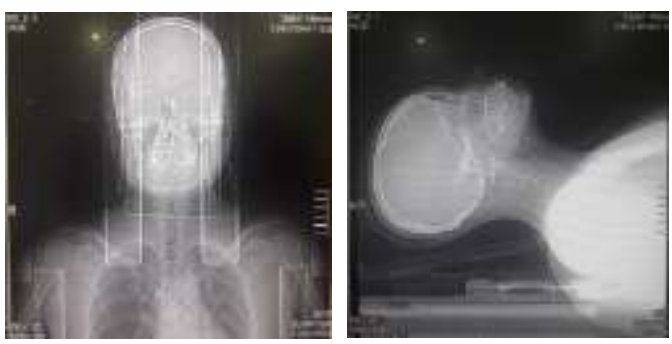

Gambar 2. Dual Scanogram proyeksi AP dan Lateral 
6) Setelah didapatkan posisi true AP lalu dipasang fiksasi kepala dengan memakai Thermoplastik Mask 3 point.

7) Dipasang tanda garis bantu midline kepala dan leher pada thermoplastik mask.

8) Memasang dan menandai titik CT Reference sebagai titik referensi untuk pergeseran di penyinaran (isosenter) (Khan et al., 2014).

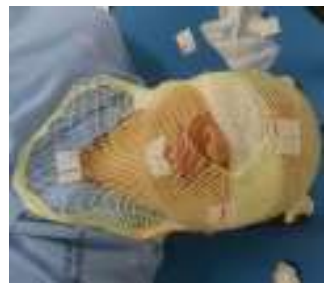

a

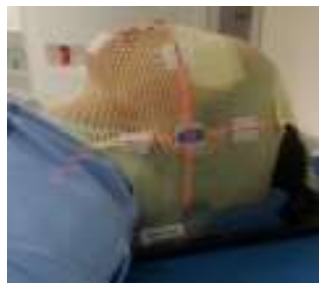

b
Gambar 3. Penempatan Marker (a) pada posisi AP, (b) pada posisi lateral sebagai CT Reference.

9) Selanjutnya melakukan proses scanning kembali dari pembuatan dual scanogram dan dilanjutkan scanning aksial dari vertex sampai fossa supraklavikula dengan ketebalan potongan (slice thickness) $2 \mathrm{~mm}$.

10) Memastikan pada hasil scanning bahwa pada meja $0 \mathrm{~cm}$ terdapat juga gambaran 3 marker pada sisi anterior, lateral kanan dan lateral kiri.

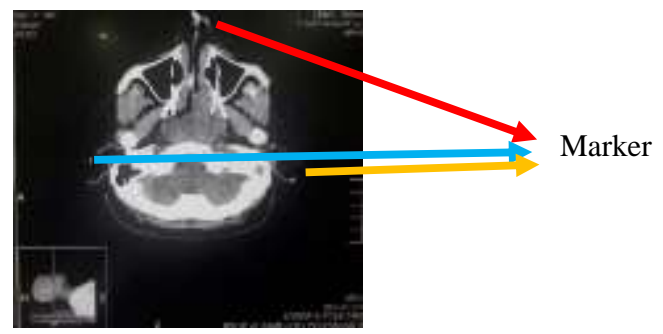

Gambar 4. Marker (3 buah) harus muncul pada salah satu potongan aksial

11) Setelah selesai proses scanning, semua gambar potongan aksial dikirim ke Treatment Planning System melalui DICOM pada Monaco (Virtual Simulasi).

\section{d.Treatment Planning System (TPS)}

1) Setelah dilakukan perencanaan pada CT Simulator, hasil CT dikirim ke Virtual Simulator Monaco dan Dokter Onkologi Radiasi melakukan delineasi (penandaan tumor dan organ kritis) pada semua potongan aksial dalam penentuan Gross
Target Volume (GTV) dan Clinical Target Volume (CTV).

2) Fisikawan Medis menentukan Planning Target Volume (PTV), yaitu Clinical Target Volume dengan ditambah 1-2 cm di luarnya CTV untuk mengurangi kesalahan menetapkan CTV dan pergerakan organ. Khusus untuk kepala penambahan margin hanya $0,5 \mathrm{~cm}$.

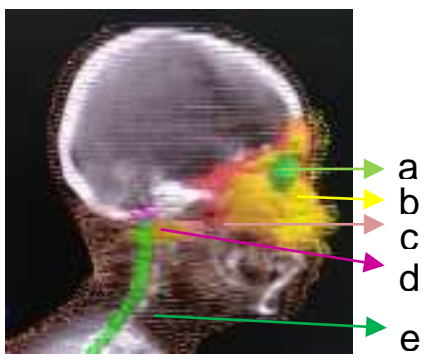

Gambar 5. Proses Delineasi di TPS

Keterangan Gambar:
a. Lensa mata
b. Gross Target Volume (GTV)
c. Clinical Target Volume (CTV)
d. Brainstem
e. Cord

3) Selanjutnya melalui Komputer Treatment Planning System Xio, data tersebut diolah untuk penentuan arah, waktu, dan dosis penyinaran dengan mempertimbangkan organ sehat mendapatkan dosis yang minimal dan jaringan yang terkena kanker mendapatkan dosis yang maksimal. Dalam hal ini teknik perencanaan yang digunakan adalah dengan menggunakan teknik 3DCRT.

4) Data yang dihasilkan oleh komputer TPS Xio untuk pasien Ny. S kasus kanker sinus paranasal adalah teknik 3DCRT dengan dosis60 Gy (@2Gy/hari) adalah:

Tabel 1. Data Output Penyinaran dari TPS

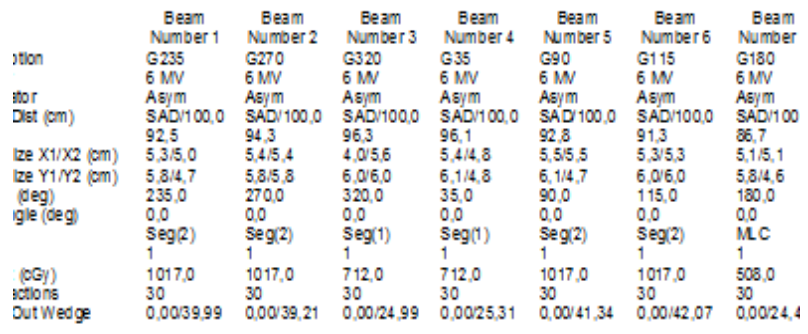

Pada tabel 1 menunjukkan hasil dari perhitungan TPS yaitu: sudut gantry, energy, kolimator, jarak set up, ukuran lapangan radiasi, dosis, MU (waktu radiasi). 

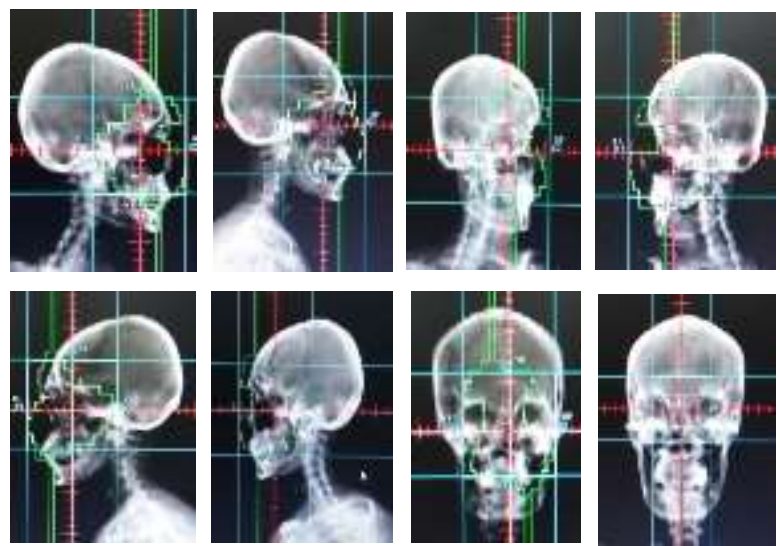

Gambar 6. Bentuk Lapangan dengan blok MLC

Pada gambar 6 menunjukkan bentuk lapangan dengan blok MLC pada masingmasing proyeksi penyinaran.

Kurva Dose Volume Histogram (DVH) dan tabelnya adalah:

Tabel 2. Dose Volume Histogram

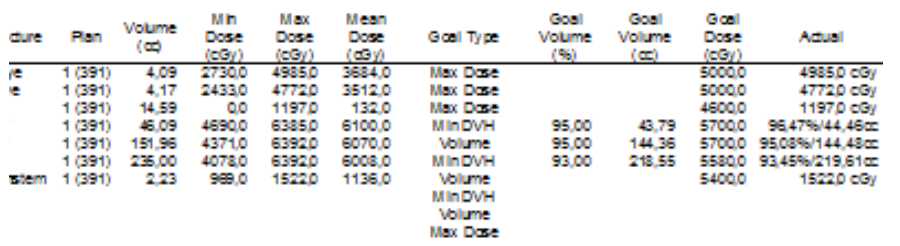

Pada tabel 2 terlihat dosis yang didapatkan oleh organ orbita kanan dan kiri, cord, GTV, CTV, PTV, Brainstem.

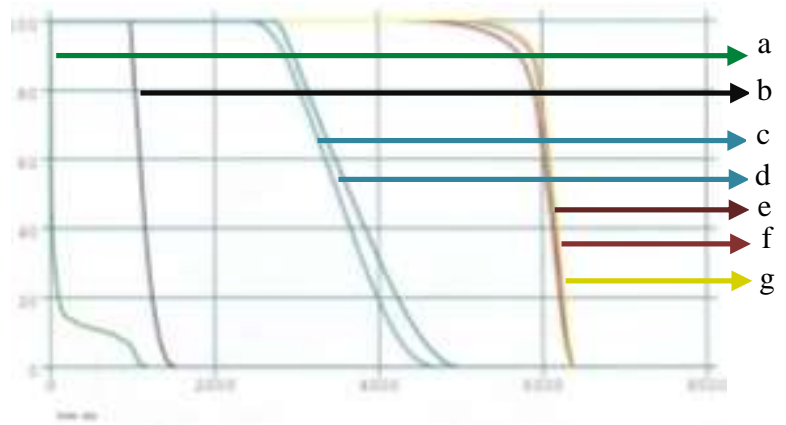

Gambar 7. Kurva Dose Volume Histogram

Keterangan Gambar:
a. Cord
e. CTV
b. Brainstem
f. PTV
c. Right Eye
g. GTV
d. Left Eye

Pada gambar 7 menunjukkan kurva volume dosis pada organ cord, brainstem, orbita kanan dan kiri, CTV, PTV, GTV.

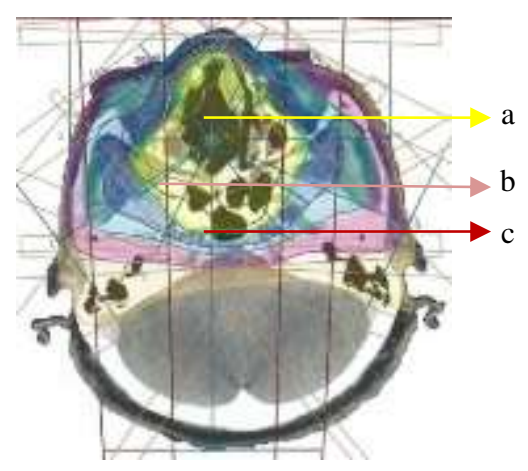

Gambar 8. Distribusi dosis pada kanker sinus paranasal dan organ at risk

Keterangan Gambar:
a. Gross Target Volume (GTV)
b. Clinical Target Volume (CTV)
c. Planning Target Volume (PTV)

Pada gambar 8 menunjukkan distribusi dosis pada target GTV, CTV, PTV dan organ at risk disekitar sinus paranasal.

e. Verifikasi Geometri

1) Posisioning pasien sesuai dengan data dari CT Simulator dan alat bantu fiksasi yang digunakan.

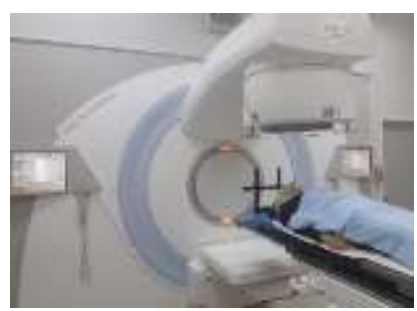

Gambar 9. Posisioning Pasien dan Fiksasi

2) Memasang bolus pada area lapangan radiasi.

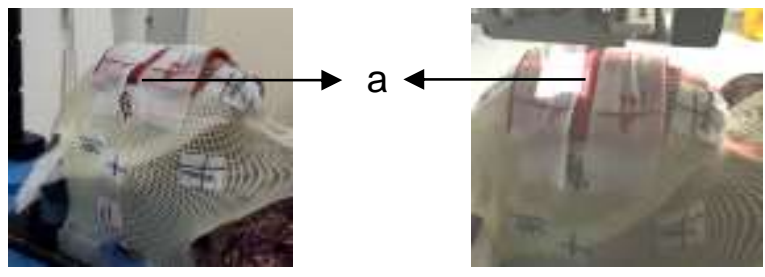

Gambar 10. Posisi Pemasangan Bolus (a)

3) Pergeseran titik dari CT Reference Point berdasarkan data pergeseran dari TPS. 
4) Proses verifikasi set up penyinaran posisi AP dan Lateral (Gantry $0^{\circ}$ dan Gantry $270^{\circ}$ )

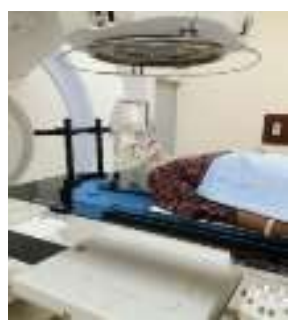

a

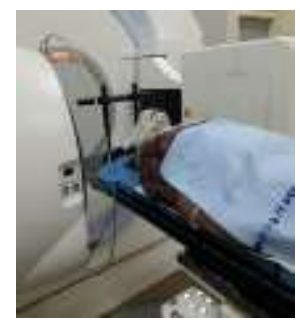

b

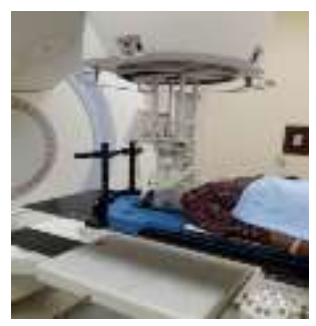

c

Gambar 11. Proses Verifikasi set up penyinarandengan EPID Posisi AP (a), Lateral Kanan (b) dan Elektron (c)

5) Verifikasi dengan menggunakan software IView GT, pencocokan gambar radiograf/DRR (Digital Reconstruction Radiograf) proyeksi AP dan Lateral dengan kondisi aktual penyinaran.

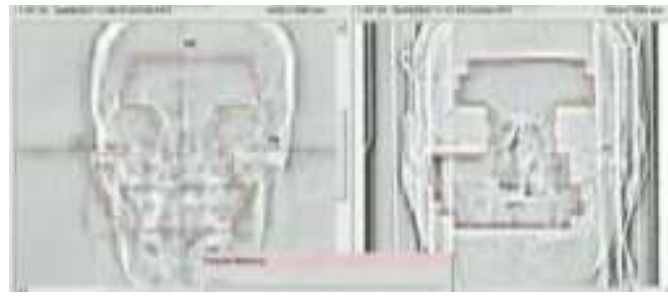

a b

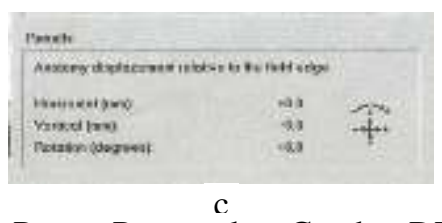

Gambar 12. Proses Pencocokan Gambar DRR (a) dan Aktual (b) Proyeksi AP dan Hasil Koreksinya (c)

Gambar 14 Proses pencocokan gambar DRR dengan aktual proyeksi AP dengan nilai pergeseran horizontal sejauh $0 \mathrm{~mm}$ (tidak ada pergerseran), vertikal sejauh 0 $\mathrm{mm}$ (tidak ada pergeseran), rotasi $0 \mathrm{~mm}$ (tidak ada pergeseran).

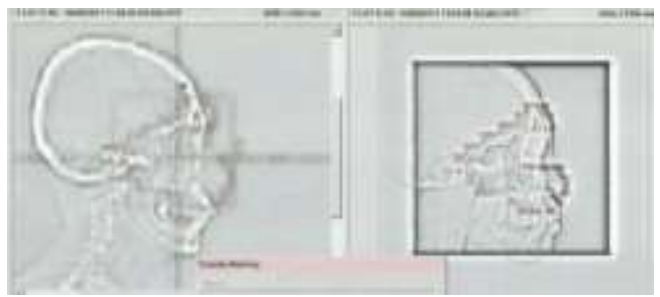

a

b

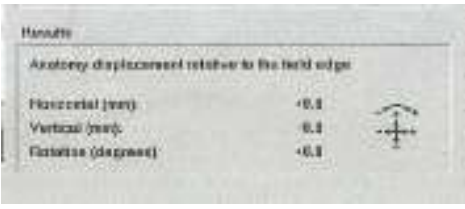

c

Gambar 13. Proses Pencocokan Gambar DRR (a) dan Aktual (b) Proyeksi Lateral Kanan dan Hasil Koreksinya (c)

Gambar 15 adalah proses pencocokan gambar DRR dengan aktual proyeksi Lateral dengan nilai pergeseran horizontal sejauh $0 \mathrm{~mm}$ (tidak ada pergerseran), vertikal sejauh $0 \mathrm{~mm}$ (tidak ada pergeseran), rotasi $0 \mathrm{~mm}$ (tidak ada pergeseran).

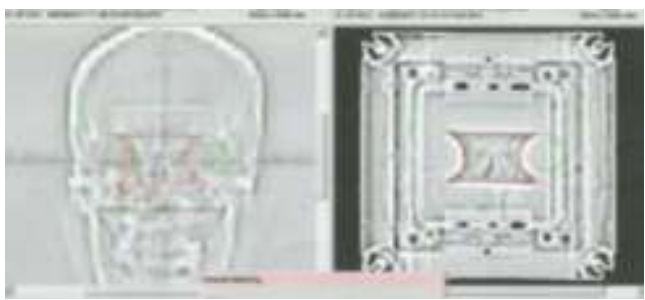

a

b

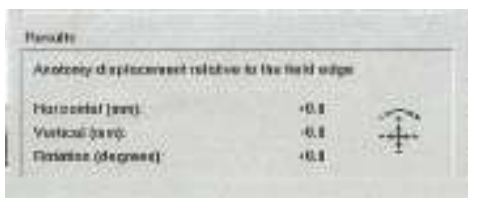

$\mathrm{C}$

Gambar 14. Proses Pencocokan Gambar DRR (a) dan Aktual (b) Proyeksi AP dengan radiasi Elektron dan Hasil Koreksinya (c)

Gambar 16 adalah proses pencocokan gambar DRR dengan aktual proyeksi AP elektron dengan nilai pergeseran horizontal sejauh $0 \mathrm{~mm}$ (tidak ada pergerseran), vertikal sejauh $0 \mathrm{~mm}$ (tidak ada pergeseran), rotasi $0 \mathrm{~mm}$ (tidak ada pergeseran).

6) Komputer IView GT akan mengambil kesimpulan sejauh mana pergeseran dari 
DRR yang dibuat dari TPS dengan posisioning dalam penyinaran.

7) Setelah tidak ada pergeseran kembali, pergeseran titik sentrasi yang baru diberi tanda untuk selanjutnya disebut sebagai titik Isocentre

8)

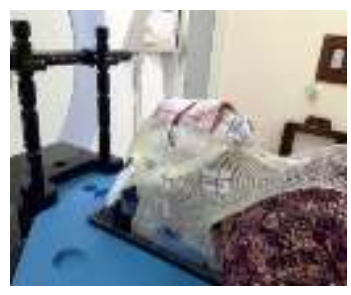

a

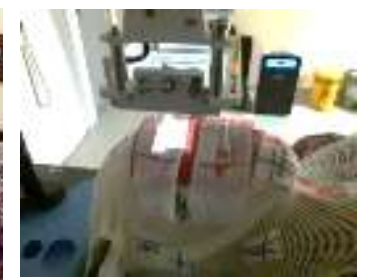

b
Gambar 15. Titik CT Reference (a) tanda plus warna biru dan Isocentre tanda plus warna hitam di lingkari (b) untuk radiasi elektron (tanda merah)

9) Untuk menjamin kualitas dan keakurasian dalam penyinaran, proses verifikasi ini dilakukan pada penyinaran ke 1, 2, 3, 10, 20 untuk teknik 3DCRT.

10) Toleransi pergeseran untuk teknik penyinaran 3DCRT adalah $0,2 \mathrm{~cm}$.

f. Tata Laksana penyinaran 3DCRT pada pasien kanker sinus paranasal

1) Posisioning pasien sesuai dengan data dari CT Simulator dan alat bantu fiksasi yang digunakan.

2) Menempatkan laser sagital, koronal dan aksial pada tanda isocentre (tanda plus warna hitam di lingkari) yang ada di thermoplastik mask.

3) Masuk ke komputer Sequencer Mosaiq

4) Klik Chart, Klik Treat dan akan muncul site set up untuk proses verifikasi apakah sudah dilakukan atau belum dan klik record.

5) Pilih lapangan radiasi dan klik treat.

6) Dalam radiasi dengan teknik 3DCRT dengan bantuan komputer Mosaiq, semua data penyinaran dapat dilakukan secara otomatis dan dikirimkan ke pesawat Linac.

7) Setelah semua siap dan komputer Linac Control System tidak ada inhibits (warna hijau di layar), siap untuk dilakukan proses radiasi.

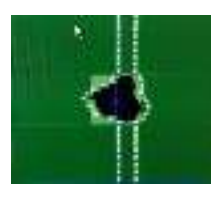

a

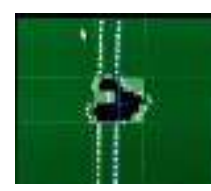

$\mathrm{f}$

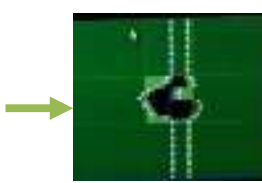

b
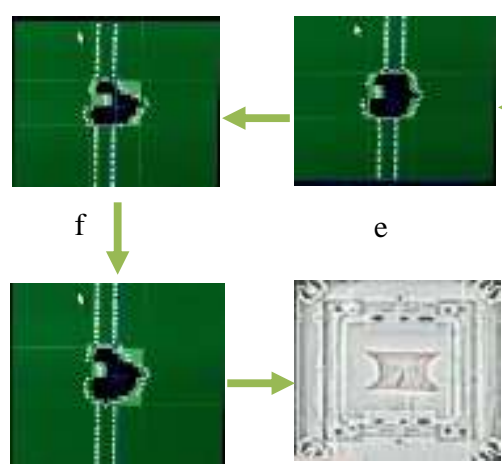

g

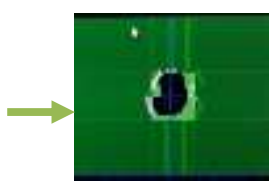

c
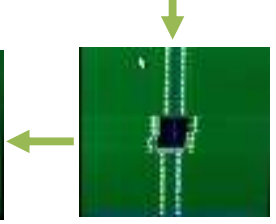

d
Gambar 16. Perubahan Bentuk Lapangan dengan pengaturan Multi Leaf Collimator (MLC)

Keterangan Gambar:

a. Bentuk MLC pada Gantry $235^{\circ}$

b. Bentuk MLC pada Gantry $270^{\circ}$

c. Bentuk MLC pada Gantry $320^{\circ}$

d. Bentuk MLC pada Gantry35 ${ }^{0}$

e. Bentuk MLC pada Gantry $90^{\circ}$

f. Bentuk MLC pada Gantry $115^{\circ}$

g. Bentuk MLC pada Gantry $180^{\circ}$

h. Bentuk blok pada radiasi electron Gantry $0^{0}$

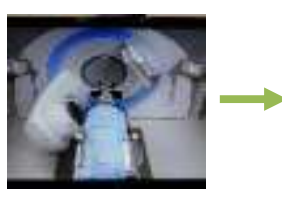

a

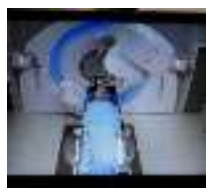

$\mathrm{f}$

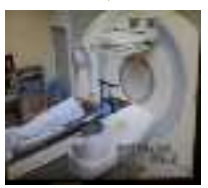

Gambar 17. Arah Perputaran Gantry Penyinaran

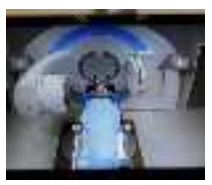

b

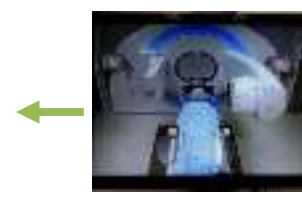

e

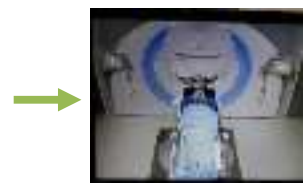

$\mathrm{h}$

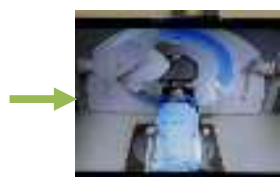

c

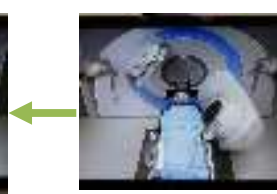

d
Keterangan Gambar:
a. Gantry $235^{\circ}$
b. Gantry $270^{\circ}$ $115^{0}$ 

c. Gantry $320^{\circ}$
$180^{\circ}$
d. Gantry $35^{0}$
g. Gantry
h. Gantry $0^{0}$

2. Implementasi teknik radioterapi 3DCRT pada pasien kanker sinus paranasal dengan penggunaan alat bantu beam modifier bolus.

Penyinaran pada kanker sinus paranasal yang dilakukan pada penelitian ini menggunakan teknik 3DCRT dengan penambahan beam modifier bolus. Bolus yang digunakan terbuat dari bahan plastisin yang ukurannya disesuaikan dengan hasil perhitungan TPS yaitu $10 \times 10 \mathrm{~cm}$ dan tebal $0,5 \mathrm{~cm}$.

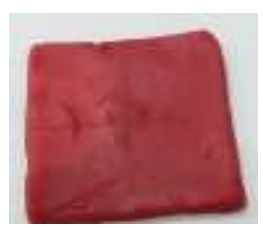

Gambar 18. Bolus dari plastisin

Bolus dipasang pada area radiasi dengan batas atas sinus frontalis dan batas bawah nasal.

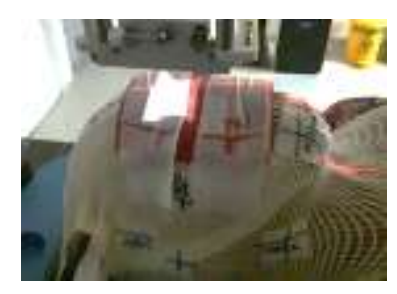

Gambar 19. Letak pemasangan bolus

Bolus dipasang pada area radiasi yang permukaannya tidak rata. Tujuan dari penggunaan bolus ini adalah untuk membuat radiasi menjadi homogen sehingga sebaran dosis pada target dapat optimal.

3. Optimalisasi hasil kurva isodosis dengan adanya penambahan radiasi elektron

Berdasarkan hasil perhitungan yang didapatkan dari TPS untuk mangatasi kekurangan dosis maka dilakukan optimalisasi dosis pada penyinaran kanker sinus paranasal teknik 3DCRT yaitu selain penambahan bolus masih perlu ditambah dengan radiasi elektron. Hal ini disebabkan karena letak target yang berada hampir di permukaan dan berdekatan dengan organ kritis (di antara dua orbita) sehingga untuk hasil radiasi yang optimal harus ditambah dengan radiasi elektron.

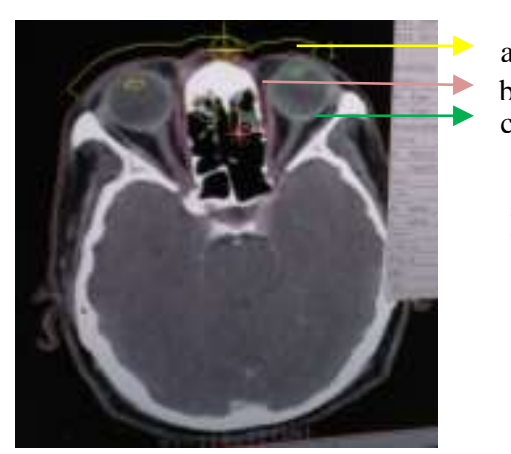

a

b

Keterangan Gambar:

a. GTV

b. CTV

c. Lensa

Gambar 20. Hasil delineasi untuk perencanaan elektron

Alasan penggunaan radiasi elektron karena karakteristik daya tembus dari radiasi elektron yang pendek atau terbatas sehingga hanya efektif apabila digunakan untuk terapi radiasi permukaan. Pada penyinaran dengan radiasi elektron ini menggunakan energi $10 \mathrm{MeV}$, teknik SSD $100 \mathrm{~cm}$, aplikator elektron ukuran $6 \times 6 \mathrm{~cm}$ dengan blok individual, gantry $0^{0}$, collimator $0^{\circ}$, dan waktu radiasi 121,99 MU

1. Teknik radioterapi 3DCRT pada pasien kanker sinus paranasal di Unit Radioterapi Instalasi Radiologi RSUP Dr. Sardjito Yogyakarta

Prinsip tatalaksana pelayanan radioterapi dalam perencanaan terapi radiasi mengacu pada protap yang ada yang telah disepakati di RSUP Dr Sardjito, dalam hal ini prosedur tindakan teknik radioterapi pada setiap pasien kanker sinus paranasal yang akan mendapatkan pengobatan radiasi diawali dengan tindakan CT simulator, TPS, Verifikasi dan Treatment (pengobatan radiasi). Hal ini sesuai dengan teori (Beyzadeoglu et al., 2010) bahwa radioterapi 3DCRT hanya mungkin dilakukan jika memiliki fasilitas Linear Accelerator (Linac) dengan multileaf collimator (MLC) dan filter wedge terpadu, Treatment Planning System (TPS) 3DCRT, dan CT Simulator multislice dan laser bergerak (Mirul, 2016).

Pada tindakan TPS, data hasil CT simulator dengan kontras di transfer dari CT simulator ke komputer TPS melalui DICOM, untuk dilakukan delineasi oleh dokter onkologi, menentukan target GTV (Gross Tumor Volume), CTV (Clinical Tumor Volume), PTV (Planning Tumor Volume), menentukan organ at risk disekitar tumor, dan melakukan perhitungan dari beberapa sudut lapangan radiasi oleh fisika medik. Setelah dilakukan perhitungan, didapatkan hasil nilai DVH (Dose Volume Histogram) yang dapat 
memberikan nilai optimum dosis radiasi pada target maupun organ at risk disekitar tumor. Dari TPS kemudian di transfer ke Mosaiq pada Linac. Hal ini sesuai teori (Beyzadeoglu et al., 2010) bahwa proses untuk melakukan radioterapi konformal 3D perlu keahlian dari spesialis onkologi radiasi untuk mendelineasi GTV, CTV dan PTV, serta organ kritis disekitar tumor/organ at risk (OAR) (Perez, 2008; Surakardja, 2000).

Pada tindakan verifikasi, data di peroleh dari server Mosaiq yang dikirim oleh TPS. Data yang diperoleh dari TPS tidak hanya data waktu penyinaran saja (MU) tetapi disertai dengan data Image berupa DRR (Digital Reconstruction Radiograph). Dengan adanya data DRR maka dapat dilakukan verifikasi terhadap organ yang akan disinar. Hal ini sesuai dengan teori Conway (2010) bahwa dua elemen utama simulasi virtual untuk akurasi dan verifikasi pengobatan pasien individu adalah transfer koordinat (tanda isocenter, tepi lapangan, posisi blok), dan pembuatan DRR.

Dalam menjalani penyinaran, tidak perlu adanya persiapan sebelum melakukan pemeriksaan, akan tetapi penderita harus kooperatif, dikarenakan penyinaran kanker sinus paranasal memerlukan waktu yang relatif lama dan tidak boleh ada pergerakan, sebelum dilakukan penyinaran pasien harus diberikan informasi jalannya penyinaran.

Kenyamanan disaat pelaksanakan penyinaran sangat diharapkan bagi pasien, dikarenakan waktu penyinaran yang relatif lama dan tidak boleh ada pergerakan, maka diperlukan sarana yang memadai untuk menunjang kenyamanan tersebut antar lain alat bantu berupa head support, masker, selimut, bisa juga diperdengarkan suara musik agar pasien tidak tegang dalam menjalani penyinaran.

Selain ketepatan teknik yang digunakan ada faktor lain yang tidak kalah penting yaitu keteraturan dan kedispilinan pasien dalam menjalani terapi radiasi. Karena apabila terapi radiasi tidak dijalani sesuai perencanaan hasil yang didapatkan tidak akan maksimal sesuai yang diharapkan.

2. Implementasi teknik radioterapi 3DCRT pada pasien kanker sinus paranasal dengan penggunaan alat bantu beam modifier bolus.

Pada prinsipnya pelaksanaan penyinaran teknik radioterapi 3DCRT pada pasien kanker sinus paranasal dengan penggunaan alat bantu beam modifier bolus sama dengan teknik penyinaran teknik radioterapi 3DCRT pada pasien kanker sinus paranasal yang tidak menggunakan bolus dari mulai tindakan CT Simulator, TPS, Verifikasi dan Treatment (pengobatan radiasi), hanya pada teknik penggunaan bolus tergantung dari letak target dan besar target. Pada umumnya letak target disekitar nasal sampai dengan sinus frontalis bentuk anatomi tubuh sangat tidak rata, sehingga dapat mengakibatkan sebaran dosis pada daerah tersebut tidak homogen dan tidak terjangkau.

Untuk mendapatkan sebaran dosis yang homogen dan terjangkau maka diperlukan alat kompensasi berupa bolus dari bahan plastisin yang mempunyai densitas hampir menyerupai densitas jaringan yaitu $1 \mathrm{gr} / \mathrm{cm}^{3}$ selain itu bahan bolus yang digunakan lunak sehingga mudah dibentuk, dapat disesuaikan dengan kontur target dan diletakan disekitar daerah nasal sampai dengan sinus frontalis. Hal ini sesuai dengan teori (Beyzadeoglu et al., 2010) bahwa bolus merupakan material yang equivalen dengan jaringan yang digunakan utk mengurangi kedalaman $\mathrm{D}_{\max }$. Tebal bolus tergantung dari hasil perhitungan di TPS, untuk kasus ini memerlukan tebal bolus sebesar $0,5 \mathrm{~cm}$ dengan ukuran $10 \mathrm{~cm}$ x $10 \mathrm{~cm}$.

Menurut pengamatan penulis penggunaan bolus memerlukan kecermatan dan ketelitian yang lebih dibandingkan penyinaran yang tanpa menggunakan bolus, karena radioterapis harus memasang bolus tersebut tepat pada target dan seluruh lapangan radiasi harus masuk. Hal ini menjadi faktor penyulit dalam penyinaran, karena apabila pemasangan tidak tepat akan berakibat sebaran dosis pada target tidak homogen dan tidak bisa optimal.

\section{Optimalisasi hasil kurva isodosis dengan adanya penambahan radiasi elektron}

Dari hasil perhitungan TPS, pada organ target yang berada tidak jauh dari permukaan disekitar daerah nasal sampai dengan sinus frontalis dan berada diantara dua orbita mengakibatkan dosis pada target tidak terjangkau meskipun sudah diberi bolus, sehingga perlu adanya penambahan radiasi disekitar daerah tersebut dengan menggunakan energi elektron, hal ini disebabkan untuk energi elektron paling baik digunakan pada target yang berada didaerah permukaan. Dengan adanya penambahan radiasi elektron maka dosis pada target daerah tersebut mendapatkan dosis optimal sekitar $100 \%$.

Hal ini sesuai dengan teori (Beyzadeoglu et al., 2010) bahwa teknik radioterapi elektron adalah teknik radioterapi yang digunakan untuk pengobatan atau terapi sel kanker atau tumor ganas yang letaknya di permukaan tubuh. Hal ini 
dikarenakan karakteristik daya tembus dari radiasi elektron yang pendek atau terbatas sehingga hanya efektif apabila digunakan untuk terapi radiasi permukaan. Dibutuhkan alat aplikator sebagai aksesoris yang bertujuan supaya dosis radiasi tetap homogen dan tetap maksimal pada target tumornya.

Menurut pengamatan penulis hal tersebut sudah sesuai dengan pelaksanaan di lapangan yaitu radiografer memasang aplikator elektron dengan penambahan blok elektron individual yang bentuknya dibuat sesuai dengan hasil perhitungan TPS.

\section{Simpulan}

Dari uraian tentang prosedur radioterapi dengan teknik 3DCRT pada kanker sinus paranasal dengan modalitas Linac di Unit Radioterapi Instalasi Radiologi RSUP Dr. Sardjito Yogyakarta maka dapat disimpulkan sebagai berikut:

1. Teknik 3DCRT pada kanker sinus paranasal menggunakan 2 jenis radiasi yaitu radiasi foton 6 MV dan radiasi elektron $10 \mathrm{MeV}$ dengan tambahan beam modifier bolus berukuran $10 \times 10$ $\mathrm{cm}$ ketebalan $0,5 \mathrm{~cm}$. Radiasi foton menggunakan teknik SAD $100 \mathrm{~cm}$ yang terdiri dari 7 lapangan penyinaran dengan sudut gantry $235^{\circ}, 270^{\circ}, 320^{\circ}, 35^{\circ}, 90^{\circ}, 115^{\circ}$ dan $180^{\circ}$. Waktu penyinaran untuk masing-masing lapangan yaitu 39,99 MU, 9,21 MU, 24,99 MU, 25,31 MU, 41,34 MU, 42,07 MU dan 24,41 MU. Radiasi Elektron menggunakan teknik SSD $100 \mathrm{~cm}$ dengan lapangan penyinaran berukuran 6 × $6 \mathrm{~cm}$ dan blok individual, waktu radiasinya sebesar 121,99 MU. Dalam kasus ini digunakan teknik 3DCRT karena pertimbangan letak target tumor yang berada di daerah yang dikelilingi organ at risk. Selain itu teknik 3DCRT di nilai mempunyai distribusi dosis yang homogen dan merata dibandingkan dengan teknik 2D sehingga untuk saat ini teknik 3DCRT menjadi pilihan terbaik untuk kasus kanker sinus paranasal.

2. Implementasi penyinaran teknik radioterapi 3DCRT pada pasien kanker sinus paranasal dengan penggunaan alat bantu beam modifier bolus sama dengan teknik penyinaran teknik radioterapi 3DCRT pada pasien kanker sinus paranasal yang tidak menggunakan bolus mulai dari tindakan CT simulator, TPS, Verifikasi dan Treatment (pengobatan radiasi), hanya pada teknik penggunaan bolus tergantung dari letak target dan besar target. Pada umumnya letak target disekitar nasal sampai dengan sinus frontalis bentuk anatomi tubuh sangat tidak rata, sehingga perlu adanya bolus untuk mendapatkan sebaran dosis pada daerah tersebut homogen dan terjangkau akibat dari target yang besar. Bolus yang digunakan terbuat dari plastisin, dengan ukuran $10 \mathrm{~cm}$ x $10 \mathrm{~cm}$ ketebalan $0,5 \mathrm{~cm}$ dipasang di daerah frontal sampai nasal.

3. Untuk mendapatkan hasil kurva isodosis yang optimal pada teknik radioterapi 3DCRT pasien kanker sinus paranasal diperlukan adanya penambahan radiasi elektron, biasanya dilakukan pada organ target yang berada tidak jauh dari permukaan disekitar daerah nasal sampai dengan sinus frontalis bertujuan untuk meningkatkan dosis pada target permukaan, sehingga dengan adanya penambahan radiasi elektron didapatkan dosis yang optimal mendekati $100 \%$ pada daerah permukaan. Energi yang digunakan untuk radiasi elektron ini sebesar $6 \mathrm{MeV}$.

\section{Daftar Pustaka}

Aird, E. G. A., \& Conway, J. (2002). CT simulation for radiotherapy treatment planning. The British Journal of Radiology, 75(900), 937-949. https://doi.org/10.1259/bjr.75.900.750937

Beyzadeoglu, M., Ozyigit, G., \& Ebruli, C. (2010). Basic Radiation Oncology (1st ed.). Springer Berlin Heidelberg. https://doi.org/10.1007/978-3-64211666-7

Carrau, R. L. (2013). Malignant Tumors of the Nasal Cavity. Otolaryngology and Facial Plastic Surgery. https://emedicine.medscape.com/article/846995overview

Dhingra, P. L. (2010). Anatomy of Nose. in : Disease of Ear, Nose, and Throat. Elsevier Mosby.

Khan, F., Reinstein, L. E., \& Podgorsak, M. B. (2014). Treatment Planning in Radiation Oncology: Patient Positioning and Immobilization (2nd ed.). Lippincott Williams \& Wilkins.

Lesmono, B. (2015). Tumor Sinonasal. Fakultas kedokteran UNPAD.

Mirul, K. (2016). Prinsip Kerja Akselerator Linier (LINAC). $\mathrm{http}: / / \mathrm{k}$ sience.blogspot.co.id/2016/03/prinsip-kerjaakselerator-linier-linac.html

NN. (2017). Nasal Cavity and Paranasal Sinus Cancer. American Society of Clinical Oncology. http://www.cancer.net/cancer-types/nasal-cavityand-paranasal-sinus-cancer

Perez. (2008). Principles and Practice of Radiation Oncology (5th ed.). LW.

Shavilla, E., Aroeman, N. A., Dewi, Y. A., \& Permana, A. D. (2016). Prevalensi Kanker Sinonasal di Poliklinik THT-KL RS.Hasan Sadikin Bandung, Januari 2013 - Juli 2015. TUNAS MEDIKA JURNAL KEDOKTERAN \& KESEHATAN, 3(1). 
http://jurnal.unswagati.ac.id/index.php/tumed/artic le/view/31

Siregar, B. (2005). Head and Neck, Breast, Soft Tissue, Skin Tumor. Oncology Surgery Dept. of Hasanuddin University.

Slomski, G. (2002). Paranasal Sinus Cancer, Gale Encyclopedia of Cancer. http://www.encyclopedia.com/c/2981-literatureand-arts.html

Soepardi, E. A., Iskandar, N., Bashiruddin, J., \& Restuti, R. D. (2007). BUKU AJAR ILMU KESEHATAN : TELINGA HIDUNG TENGGOROKAN KEPALA \& LEHER Edisi 6.
Surakardja, I. (2000). Onkologi Klinik. Fakultas kedokteran Universitas Airlangga/RSUD Dr. Soetomo.

Susworo, R. (2006). Dasar-Dasar Radioterapi Tata Laksana Radioterapi Penyakit Kanker. Universitas Indonesia. 